\title{
Peningkatan Motivasi Dan Hasil Belajar IPA Materi Pencemaran Lingkungan Melalui Model PjBL Siswa Kelas VII SMPN 9 Salatiga
}

\author{
Anis Wahdati Sholekah ${ }^{1{ }^{*}}$ \\ ${ }^{1)}$ Program Studi Tadris IPA FTIK IAIN Salatiga \\ *aniswahdati19@gmail.com
}

Abstrak: Penelitian ini dilatar belakangi oleh rendahnya motivasi dan hasil belajar IPA kelas VII-H di SMPN 9 Salatiga. Berdasarkan observasi dan wawancara penyebab rendahnya motivasi dilihat ketika proses pembelajaran. Sedangkan hasil belajar rendah dilihat UAS semester I nilai rata-rata 35,10 dengan KKM 76. Penelitian ini bertujuan untuk mengetahui peningkatan motivasi dan hasil belajar IPA menggunakan model PjBL materi pencemaran lingkungan. Jenis penelitian menggunakan PTK dengan 2 siklus. Teknik pengumpulan data yang digunakan adalah observasi, angket, tes, wawancara dan dokumentasi pada pembelajaran pencemaran lingkungan melalui model PjBL. Hasil penelitian menunjukkan bahwa penerapan model PjBL dapat meningkatkan motivasi dan hasil belajar IPA materi pencemaran lingkungan pada siswa kelas VII-H SMP Negeri 9 Salatiga. Keberhasilan penelitian dapat ditunjukan melalui angket motivasi dan tes evaluasi yang diperoleh setiap siklusnya. Motivasi belajar kategori tinggi yaitu $\geq 50$ dan standar KKM mata pelajaran IPA yaitu 76 dengan pencapaian klasikal 85\% untuk hasil belajar. Peningkatan ini dapat dilihat dari siklus I motivasi belajar siswa dengan rata-rata $41,31 \%$ dan meningkat pada siklus II menjadi $69,34 \%$. Sedangkan peningkatan hasil belajar IPA pada siklus I 27,6\% dan meningkat pada siklus II menjadi 89,7\% yang tuntas. Sehingga dapat disimpulkan bahwa model PjBL dapat dapat meninfkatkan motivasi dan hasil belajar IPA serta dikatakan berhasil.

Kata Kunci: Motivasi Belajar, Hasil Belajar, IPA dan Model Project Based Learning (PjBL)

\section{Pendahuluan}

Pembelajaran IPA merupakan kumpulan ilmu yang memiliki ciri khusus yaitu mempelajari fenomena alam yang konkret, berupa kenyataan dan berkaitan dengan sebab-akibatnya dalam pembelajarannya. Proses pembelajaran IPA terdiri tiga tahap yaitu perencanaan, pelaksanakan dan penelitian hasil pembelajaran (Wisudawati \& Eka, 2017: 22-26). Sedangkan menurut Abdullah (dalam Kurniawan, 2019: 22) menyatakan bahwa IPA merupakan pengetahuan teoritis yang didapatkan atau dirangkai dengan beberapa tahapan khusus, yaitu dengan melakukan percobaan, observasi, penyimpulan, penyusunan teori, dan demikian seterusnya berkaitan dengan tahap satu dengan lainnya dalam pembelajaranya. Pembelajaran dalam IPA mengutamakan pada pemberian pengalaman secara langsung guna mengelaborasikan kompetensi agar menjelajahi dan memahami alam sekitar secara ilmiah yang terkandung dalam proses pembelajarannya (Trianto, 2015: 153).

Suatu proses pembelajaran tidaklah luput dengan adanya motivasi. Maka motivasi diartikan sebagai kekuatan, dari dalam ataupun dari luar yang mendorong seseorang untuk mencapai suatu tujuan tertentu (Uno, 2016: 1). Sehubungan dengan hal tersebut, motivasi telah dijelaskan dalam Al-Qur'an bahwa memotivasi dan mengarahkan setiap manusia untuk belajar, sebagaimana firman Allah SWT dalam QS.Al-Mujadalah ayat 11 yang berbunyi:

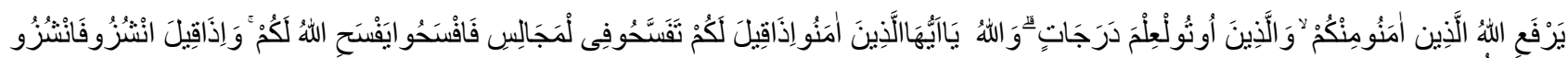

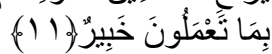
Artinnya: "Wahai orang-orang yang beriman! Apabila dikatakan kepadamu, "Berilah kelapangan di dalam majelis-majelis" maka lapangkanlah, niscaya Allah akan memberi kelapangan untukmu. Dan apabila dikatakan, "Berdilirah kamu" maka berdirilah, ciscaya Allah akan mengangkat (derajat) orang-orang yang beriman diantaramu dan orang-orang yang diberi ilmu beberapa derajat. Dan Allah maha teliti apa yang kamu kerjakan" (QS.Al-Mujadalah ayat 11). 
Berdasarkan ayat di atas dapat diketahui bahwa seseorang bisa mendapatkan derajat di sisi Allah dengan cara beriman kepadaNya dan menjadi seseorang yang berilmu atau berpengetahuan dengan cara belajar, tentu dalam hal ini ada kolerasi dalam keduanya. Kedua hal itu bisa menjadi landasan untuk memotivasi seseorang untuk mendapatkan derajat di sisi Allah SWT dengan dua cara tersebut yaitu menjadi orang yang beriman dan berilmu. Oleh karena berdasarkan dengan mendapatkan derajat di sisi Allah SWT maka seseorang termotivasi untuk belajar, dengan belajarlah seseorang bisa menjadi orang yang berilmu dan berpengetahuan, dan ilmu sebagai jembatan seseorang untuk menjadi orang yang beriman, dan apabila keduanya sudah tercapai maka akan mendapatkan derajat di sisi Allah SWT.

Berdasarkan hasil observasi dan wawancara yang dilakukan oleh peneliti dengan guru yang mengajar kelas VII-H SMP Negeri 9 Salatiga didapatkan informasi bahwa motivasi dan hasil belajar IPA masih rendah dibandingkan dengan mata pelajaran lainnya. Rendahnya motivasi belajar dilihat ketika proses pembelajaran berlangsung, siswa coret-coret buku atau menggambar sendiri, mengobrol dengan teman sebangkunya, kebingungan saat ditanya cita-citannya, melamun saat guru menjelaskan materi dan pembelajaran terkesan monoton sehingga siswa kesulitan dalam memahami materi yang disampaikan oleh guru berdampak pada rendahnya hasil belajar siswa.

Hasil belajar siswa kelas VII-H yang merupakan subjek penelitian masih banyak siswa yang nilainya kurang dari KKM. Hal ini ditandai ketika siswa dihadapkan dengan soal, siswa tidak dapat melakukan generalisasi dari informasi yang disajikan pada soal untuk membantunya dalam menemukan jawaban, mereka hanya menebak jawaban tersebut, ketika pembelajaran berlangsung siswa kurang memperhatikan apa yang disampaikan oleh guru sehingga banyak siswa yang belum mencapai KKM yaitu 76, sehingga berdampak pada persentase hasil belajar Ulangan Akhir Semester (UAS) I di kelas VII-H yang mendapatkan nilai tertinggi hanya sebesar 60 sehingga dapat dikatakan ketuntasan adalah $0 \%$, dengan nilai rata-rata hasil belajar IPA 35,10 dan harus melakukan remedial. Sementara nilai siswa pada mata pelajaran lain sebagian besar nilainya lebih baik. Artinya siswa masih mengalami kesulitan dalam pembelajaran dan belum mencapai kriteria yang sudah ditetapkan dari jumlah siswa.

Permasalahan yang sering terjadi dalam proses pembelajaran di SMPN 9 Salatiga khususnya mata pelajaran IPA, pemilihan metode/model pembelajaran yang kurang tepat berakibat pembelajaran belum berjalan dengan baik. Selain aktivitas yang dilakukan sebagian siswa di atas, kompetensi siswa masih belum sesuai dengan yang di harapkan yaitu masih banyak siswa yang mendapatkan nilai di bawah KKM dan kurang adanya inovasi dalam mengembangkan proses pembelajaran. Hal tersebut menuntut guru perlu menciptakan model yang tepat dan menarik perhatian siswa agar siswa mempunyai motivasi dan hasil belajar yang tinggi dalam proses pembelajaran. Salah satu pilihan model pembelajaran yang harus diterapkan dalam materi selanjutnya yaitu pencemaran lingkungan menurut peneliti dan guru kelas VII-H SMPN 9 Salatiga, untuk meningkatkan motivasi dan hasil belajar siswa dalam materi ini peneliti memilih dengan menggunakan model Project Based Learning $(\mathrm{PjBL})$.

Model pembelajaran Project Based Learning (PjBL) dipilih karena pembelajaran ini memberikan kesempatan untuk siswa bekerja lebih otonom, untuk mengembangkan pembelajaran sendiri, lebih realistik dan menghasilkan suatu produk. Pembelajaran berbasis proyek menyediakan tugas-tugas komplek yang berbasis pertanyaan-pertanyaan atau masalah yang melibatkan siswa dalam aktivitas-aktivitas memecahkan masalah, membuat keputusan, melakukan investigasi dan refleksi yang melibatkan guru sebagai fasilitator. Pembelajaran berbasis proyek terfokus pada pertanyaan-pertanyaan yang menuntun siswa untuk memanfaatkan konsep-konsep dan prinsip-prinsip melalui pengalaman. Sehingga dengan pembelajaran berbasis proyek siswa belajar dari pengalamannya dan kemudian menerapkannya dalam kehidupan sehari-hari. Model pembelajaran ini diharapkan mampu meningkatkan motivasi dan hasil belajar IPA siswa karena melalui model ini mereka akan dilatih untuk mengonstruksi sendiri pengetahuan yang mereka miliki dengan terlibat aktif dalam proses pembelajaran yang kompleks.

Berdasarkan Thomas (dalam Wena, 2016: 144) pembelajaran berbasis proyek merupakan model pembelajaran yang memberikan kesempatan kepada guru untuk mengolah pembelajaran di kelas dengan melibatkan kerja proyek sebagai metode dan mediannya. Siswa melakukan eksplorasi, penilaian, interprestasi, sintesis, dan informasi untuk mendapatkan berbagai bentuk hasil belajar. 
Pembelajaran dengan menggunakan Project Based Learning akan menumbuhkan semangat bagi siswa dan memotivasi siswa untuk belajar sehingga akan berdampak positif bagi proses pembelajarannya seperti yang dilakukan oleh penelitian sebelumnya yaitu Simbolon, (2014). menyatakan bahwa terjadi peningkatan jika dibandingkan dengan sebelum menggunakan model Project Based Learning (PjBL). Pembelajaran berbasis proyek atau biasa disebut dengan Project Based Learning (PjBL) dapat meningkatkan hasil belajar siswa daripada pembelajaran yang menggunakan pembelajaran konvensional, karena dapat menjadikan siswa merasa dirinya dilibatkan dalam proses bembelajaran, dan berkesemapatan untuk menyampaikan pendapat, gagasan, ide ataupun pertanyaan. Sehingga dapat ditarik kesimpulan bahwa pembelajaran dengan model Project Based Learning $(\mathrm{PjBL})$ dapat berpengaruh positif dalam proses pembelajarannya.

Berdasarkan dari beberapa penelitian yang dilakukan oleh peneliti sebelumnya dengan menggunakan model PjBL yang mempunyai 6 tahap seperti yang diungkapkan Rofiah, (2014) yaitu mulai pertanyaan mendasar, merancang perancanaan proyek, membuat jadwal, memantau kemajuan proyek, penilaian, dan mengevaluasi proses pembelajaran, maka dalam penelitian ini dilakukan untuk pengembangan model Project Based Learning $(\mathrm{PjBL})$ dengan asumsi model tersebut dapat digunakan untuk pembelajaran yang lebih efektif. Serta beberapa perbedaan dari penelitian terdahulu dengan penelitian ini yaitu apa yang ditingkatkan, subyek, waktu, serta materi pembelajran pada siswa kelas VII-H SMPN 9 Salatiga tahun pelajaran 2019/2020.

Menurut Moursund (dalam Wena, 2016: 147) kelebihan model Project Based Learning (PjBL) adalah memberikan pengalaman kepada siswa mengenai praktik menyusun proyek, menyediakan pengalaman belajar yang melibatkan siswa secara kompleks hal tersebut guna untuk berkembangnya siswa secara dunia nyata, diadakanya pembelajran yang menyenangkan. Sedangkan kekurangan ataupun kelemahan dari model Project Based Learning $(\mathrm{PjBL})$ adalah memerlukan banyak waktu untuk menyelesaikan proyek, banyaknya peralatan yang digunakan, ada kemungkinan siswa pasif dalam kelompok, dan membutuhkan biaya cukup banyak. Akan tetapi kelemahan-kelemahan tersebut tidak akan masalah selagi guru dapat menyusun pembelajaran dengan baik (Triana, Zulkarnain \& Rahma, 2015: 9).

Sehubungan dengan hal tersebut peneliti mencoba menerapkan sebuah tindakan dengan menggunakan model $\mathrm{PjBL}$ untuk mengatasi permasalahan yang ada, maka peniliti ingin membuktikan bahwa menggunakan model Project Based Learning (PjBL) dapat meningkatkan motivasi dan hasil belajar siswa dalam pembelajaran IPA. Penelitian Tindakan Kelas (PTK) tersebut berjudul Peningkatan Motivasi Dan Hasil Belajar Ipa Materi Pencemaran Lingkungan Melalui Model Project Based Learning (Pjbl) Pada Siswa Kelas Vii-H Smp Negeri 9 Salatiga.

\section{Metode}

Penelitian ini dilakukan menggunakan jenis Penelitian Tindakan Kelas (PTK). Penelitian dilakukan dengan dua siklus meliputi empat tahap pokok, yaitu perencanaan, pelaksanaan tindakan, pengamatan dan refleksi (Arikunto, Suhardjo \& Supardi, 2015: 143). Adapun subjek dan tempat penelitian adalah kelas VII-H SMPN 9 Salatiga yang terdiri atas 29 siswa dengan 13 siswa perempuan dan 16 siswa laki-laki. Pada pembelajaran ini peneliti menggunakan pembelajaran berbasis proyek sebagai medianya.

Teknik pengumpulan data penelitian ini meliputi observasi dilakukan melalui pengamatan dan pencatatan untuk mengetahui kelemahan proses pembelajaran, angket diberikan setiap siklusnya untuk mengukur motivasi siswa, tes diberikan untuk mengukur hasil belajar setiap siklusnya, wawancara digunakan sebagai penguat data yang ada dan dokumentasi sebagai bukti-bukti penelitian.

Data yang terkumpul kemudian dianalisis untuk mengetahui ketuntasan individu pada hasil tes evaluasi dengan rumus :

$$
\text { Nilai }=\text { Jumlah Skor } \times 5
$$

Kemudian untuk mengetahui persentase ketuntasan klasikal $\geq 85 \%$ dari jumlah siswa satu kelas dengan rumus:

$$
P=\frac{\sum n_{1}}{\sum n} \times 100 \%
$$

\section{Hasil dan Pembahasan}


Setelah dilakukan analisi data yang diperoleh dari dua siklus yang dilaksanakan pada tanggal 17-27 Februari 2020 mendapatkan hasil penelitian dengan menggunakan model Project Based Learning (PjBL) dari siklus I sampai siklus II mengalami peningkatan sesuai yang diharapkan.

Berikut adalah hasil perbandingan persiklus dari motivasi belajar dan hasil belajar pada siswa kelas VII-H SMPN 9 Salatiga materi pencemaran lingkungan melalui model Project Based Learning (PjBL).

Berdasarkan Tabel 1 diketahui bahwa peningkatan banyak siswa yang masuk kategori sangat tinggi. Meningkatnya motivasi tersebut dilihat dari hasil observasi motivasi dengan mengisi angket dengan 20 kategori yang diberikan setiap siklusnya.

Tabel 1.Hasil Rekapitulasi Motivasi Persiklus

\begin{tabular}{cclcc}
\hline Siklus & Rata-rata & Kategori & Jumlah & Persentase \\
\hline I & 41,31 & Sangat & 6 & $20,68 \%$ \\
& & Cukup & & \\
& & Cukup & 18 & $62,06 \%$ \\
& & Tinggi & 5 & $17,24 \%$ \\
II & \multirow{4}{*}{69,34} & Sangat Tinggi & 0 & $0 \%$ \\
& & Sangat & - & $0 \%$ \\
& & Cukup & & \\
& & Cukup & - & $0 \%$ \\
& & Tinggi & 2 & $6,89 \%$ \\
& & Sangat Tinggi & 27 & $93,10 \%$ \\
\hline
\end{tabular}

(Sumber Data Primer)

Hasil dari Tabel 1, menunjukkan adanya peningkatan motivasi belajar siswa setelah dilakukanya tindakan dengan membagikan angket motivasi setelah proses pembelajaran sebagai instrumen penelitian. Angket motivasi akan direspon oleh siswa sebagai bentuk alat ukur untuk mengetahui motivasi belajar siswa dalam setiap siklusnya. Pada lembar angket motivasi belajar siswa terdapat 20 pernyataan dengan empat kriteria penilaian seperti yang dikatakan oleh Wahyuni (2017) empat kriteria tersebut yaitu Sangat Cukup (SC) dengan nilai 2034, Cukup (C) dengan nilai 35-49, Tinggi (T) nilai 50-64, dan Sangat Tinggi (ST) dengan nilai 65-80. Data yang diperoleh dari motivasi belajar siswa pada kegiatan siklus I terdapat 6 siswa $(20,68 \%)$ yang memiliki kategori motivasi belajar sangat cukup, 18 siswa (62,06\%) yang memiliki kategori cukup, dan 5 siswa $(17,24 \%)$ termasuk kategori tinggi, serta 0 siswa (0\%) tergolong masuk kategori sangat tinggi. Berdasarkan data per kategori tersebut didapatkan dengan rata-rata motivasi belajar pada siklus I yaitu 41,31 termasuk kategori cukup. Data tersebut menunjukkan bahwa motivasi belajar IPA SMPN 9 Salatiga mempunyai motivasi belajar yang rendah dan kurang. Siklus I semangat siswa belum terbentuk seperti halnya untuk presentasi hasil kegiatan belajar masih malu-malu karena siswa masih belum terbiasa mengenai model $\mathrm{PjBL}$ sehingga perlu perbaikan untuk meningkatkan kekurangan pada motivasi.

Sedangkan pada siklus II agar motivasi belajar siswa dapat meningkat guru menjalankan proses pembelajaran dengan sebaik mungkin, karena memang meningkatnya motivasi ada usaha dari dalam diri sendiri maupun usaha pembentukan dari orang lain (Asrori, 2007: 183). Sehingga pada siklus II terdapat 0 siswa (\%) yang termasuk kategori sangat cukup, 0 siswa (\%) termasuk kategori cukup, dan 2 siswa (6,89\%) kategori tinggi, serta 27 siswa $(93,10 \%)$ termasuk kategori sangat tinggi. Berdasarkan data per kategori tersebut didapatkan dengan rata-rata motivasi belajar pada siklus II yaitu 69,34 termasuk kategori sangat tinggi. Peningkatan tersebut dapat dilihat pada gambar 1 sebagai berikut:

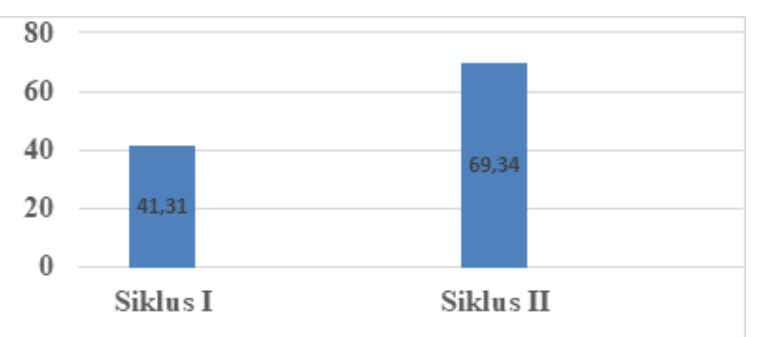

Gambar 1. Diagram Rata-rata Motivasi Belajar Persiklus 


\section{(Sumber Data Primer)}

Gambar 1, menunjukkan bahwa motivasi belajar siswa setelah diterapkan model Project Based Learning $(\mathrm{PjBL})$ terjadi peningkatan persentase rata-rata motivasi siswa kategori tinggi dari siklus I dapat dilihat 41,31\% dan siklus II 69,34\%. Peningkatan persentase motivasi kategori tinggi dari siklus I ke siklus II yaitu 28,03\%. Peningkatan sebesar 28,03\% ini tidak terlepas dari kerjasama yang baik antara peneliti dan guru dalam merancang kegiatan pembelajaran yang lebih matang lagi. Peneliti berhasil meningkatkan peningkatan motivasi belajar IPA yang lumayan memuaskan ini guru lebih tegas dalam tahapan-tahapan model pembelajaran PjBL melalui media PPT dan guru memberikan ungkapan-ungkapan motivasi serta nasehat terhadap siswa pada kelas VII-H SMPN 9 Salatiga agar mendapatkan hasil yang maksimal, selain itu juga guru membuat siswa lebih semangat dan percaya diri saat mengikuti pelajaran terutama pelajaran IPA pada saat siswa menyelesaikan tugas proyek yang diberikan oleh guru. Sehingga siswa mampu menunjukkan perkembangan terlihat hampir semua perhatian, ketertarikan menyelesaikan tugas proyek dan keingintahuan siswa di kelas menunjukkan ada perkembangan yang lebih baik menunjukkan bahwa motivasi belajar siswa meningkat dibandingkan siklus sebelumnya dikarenakan siswa sudah memahami dengan baik model pembelajaran dengan menggunakan model PjBL dengan begitu senada yang diungkapkan oleh Purwanto (2014: 319) bahwa motivasi dapat meningkat dengan memberikan daya dorong sehingga sesuatu yang dimotivasi tersebut dapat menyelesaikan apa yang dihadapinya.

Sedangkan meningkatnya hasil belajar pada setiap siklusnya dapat dilihat pada tabel 2 sebagai berikut:

Tabel 2. Hasil Rekapitulasi Hasil Belajar Persiklus

\begin{tabular}{ccccc}
\hline Siklus & Rata-rata & Kategori & Jumlah & Persentase \\
\hline I & 60,86 & Tuntas & 8 & $27,6 \%$ \\
& & Belum Tuntas & 21 & $72,4 \%$ \\
II & \multirow{2}{*}{83,62} & Tuntas & 26 & $89,7 \%$ \\
& & Belum Tuntas & 3 & $10,3 \%$ \\
\hline
\end{tabular}

(Sumber Data Primer)

Tabel 2, menunjukkan adanya peningkatan hasil belajar siswa setelah dilakukannya tindakan seperti yang diungkapkan Sudjana (2017: 2) hasil belajar didapatkan setelah mengikuti pembelajaran, pembelajaran di kelas dikatakan berhasil jika sudah mencapai tujuan pengajaran adanya peningkatan prestasi siswa. Adanya peningkatan hasil belajar pada persiklusnya, hal tersebut merupakan bukti dari keberhasilan pada saat proses pembelajaran. Data yang didapatkan dari pekerjaan siswa pada soal evalusi dikegiatan siklus I terdapat 8 siswa $(27,6 \%)$ yang tuntas, sedangkan siswa yang belum tuntas 21 siswa $(72,4 \%)$ dengan rata-rata 60,86 . Sehingga dapat dikatakan bahwa hasil belajar siswa kelas VII-H SMP Negeri 9 Salatiga pada mata pelajaran IPA masih sangat rendah dan kurang dari Kriteria Ketuntasan Minimum (KKM) yang telah ditentukan yaitu $\geq 76$. Sedangkan pada siklus II terdapat 25 siswa $(89,7 \%)$ yang tuntas dan 4 siswa (10,3\%) yang belum tuntas dengan perolehan nilai rata-rata $83,62 \%$. Data yang didapatkan pada pelaksanaan penelitian siklus II menunjukkan bahwa hasil belajar siswa dari siklus I ke siklus II ini mengalami peningkatan. Hasil belajar yang dicapai pada siklus II telah mencapai indikator keberhasilan klasikal yang ditetapkan yaitu $85 \%$ dari jumlah siswa yang diperoleh nilai tuntas $(\geq 76)$ peningkatan tersebut tidak luput dari meningkatnya hasil motivasi yang meningkat juga (Yamin: 2015: 11), sehingga penelitian tindakan kelas di kelas VII-H SMP Negeri 9 Salatiga dihentikan pada siklus II ini. Peningkatan tersebut dapat dilihat pada gambar 2 sebagai beriku:

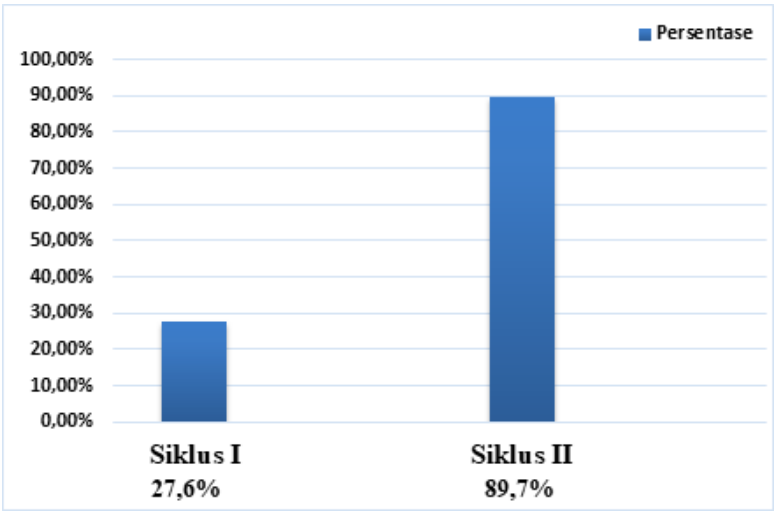


Gambar 2. Diagram Ketuntasan Hasil Belajar Persiklus (Sumber Data Primer)

Gambar 1, dilihat bahwa hasil belajar siswa menunjukkan peningkatan setelah diterapkan model pembelajaran Project Based Learning (PjBL) terjadi peningkatan dari siklus I terdapat $27,6 \%$ siswa tuntas, sedangkan siklus II 89,7\% siswa tuntas. Peningkatan siswa yang tuntas belajar dari siklus I ke Siklus II adalah $62,1 \%$. Artinya ketertarikan siswa dalam pembelajaran bisa dikatakan sangat baik dari kegiatan awal hingga akhir pada mata pelajaran IPA materi pencemaran lingkungan sehingga siswa berhasil meningkatkan dengan telah melebihi indikator keberhasilan klasikal yang telah ditentukan yaitu 85\% (IAIN Salatiga, 2017: 34). Hal ini dikarenakan peneliti yang sudah menerapkan pembelajaran menggunakan model PjBL dengan baik dan siswa sudah mengerti serta terbiasa menggunakan model pembelajaran PjBL dalam pelajaran IPA. Sehingga penelitian dapat dikatakan telah berhasil dan dihentikan pada siklus II.

Hasil penelitian peneliti yang berjudul "Peningkatan Motivasi dan Hasil Belajar IPA Materi Pencemaran Lingkungan melalui Model Project Based Learning (PjBL) pada Siswa Kelas VII SMP Negeri 9 Salatiga Tahun Pelajaran 2019/2020), dapat dikatakan relevan dan sesuai dengan penelitian yang dilakukan oleh Simbolon (2014) menunjukkan adanya peningkatan yang signifikan terhadap hasil belajarnya. Penggunaan model Project Based Learning (PjBL) pada Siswa SMP Negeri 5 Tebing Tahun Pelajaran 2013/2014, dapat ditarik kesimpulan bahwa penggunaan model tersebut menjadikan siswa merasa dirinya mendapatkan perhatian, semangat, dan kesempatan untuk menanyakan gagasan, ide ataupun pertanyaan.

\section{Simpulan}

Berdasarkan penelitian tindakan kelas (PTK) yang dilakukan 4 tahap seperti: perancanaan (Planning), pelaksanaan (action), pengamatan (observasing), dan refleksi (reflection) terhadap siswa kelas VII-H SMP Negeri 9 Salatiga pada mata pelajaran IPA materi pencemaran lingkungan melalui model Project Based Learning (PjBL) yang memiliki 6 langkah yakni mulai pertanyaan mendasar, merancang perancanaaan proyek, menyusun jadwal, memantau siswa ataupun kemajuan proyek, penilaian, dan mengevaluasi proses pembelajaran dapat disimpulkan bahwa: Penerapan model Project Based Learning (PjBL) dapat meningkatkan motivasi belajar IPA materi pencemaran lingkungan pada kelas VII-H di SMP Negeri 9 Salatiga 2019/2020. Hal ini dapat dibuktikan semakin meningkatnya rata-rata motivasi siswa dari setiap siklusnya yaitu 41,31\% pada siklus I menjadi $69,34 \%$ pada siklus II, sehingga terjadi peningkatan 28,03\%. Sedangkan penerapan model Project Based Learning (PjBL) dapat meningkatkan hasil belajar IPA materi materi pencemaran lingkungan pada kelas VII-H di SMP Negeri 9 Salatiga 2019/2020. Hal ini ditunjukkan oleh meningkatnya persentase nilai siklus I (27,6\%) dan siklus II $(89,7 \%)$ sehingga terjadi peningkatan hingga mencapai $62,1 \%$.

Menurut data tersebut dapat dikatakan bahwa pembelajaran IPA materi pencemaran lingkungan pada siswa kelas VII-H SMP Negeri 9 Salatiga Tahun Pelajaran 2019/2020 dengan menggunakan model Project Based Learning $(\mathrm{PjBL})$ dapat dikatakan telah berhasil. Sehingga penelitian dihentikan pada siklus II.

\section{Ucapan Terima Kasih}

Penulis mengucapkan terima kasih kepada keluarga besar yang selalu memotivasi, dosen pembimbing yang telah membantu dan membimbing, serta pihak SMPN 9 Salatiga yang telah mengizinkan melakukan penelitian.

\section{Daftar Pustaka}

Arikunto, Suharsini, Suhardjono, \& Supardi. 2015. Penelitian Tindakan Kelas. Jakarta: Bumi Aksara. Asrori, Muhammad. 2007. Psikologi Pembelajaran. Bandung: CV Wacana Prima.

IAIN Salatiga. 2017. Pedoman Penyusun Skripsi. Salatiga: IAIN Salatiga.

Kurniawan, Wawan. 2019. Peningkatan Hasil Belajar IPA Materi Sistem Peredaran Darah Manusia dengan Strategi Pembelajaran Group Resume pada Siswa Kelas VIII SMPN 06 Salatiga Tahun Pelajaran 2018/2029. Skripsi tidak diterbitkan. Salatiga: JurusanTadris IPA IAIN Salatiga.

Purwanto, M Ngalim. 2014. Ilmu Pendidikan Teoretis dan Praktis. Bandung: PT Remaja Rosdakarya.

Rofiah, Fikrotur. 2014. Ilmu Pendidikan Teoretis dan Praktis. (Online). (http://www.eurekapendidikan.com/2014/12/Model-projectbasedlearning-landasan.html?m=1, diakses 29 November 2019). 
Simbolon, Pasuri. 2014. Peningkatan Hasil Belajar IPA dengan Menggunakan Model Project Based Learning bagi Siswa SMP Negeri 5 Tebing Tinggi Tahun Pelajaran 2013/2014.(Online), (http://jurnal.unimed.ac.id, diakses 29 November 2019).

Sudjana, Nana. 2017. Penilaian Hasil Proses Belajar Mengajar. Bandung: PT Remaja Rosdakarya.

Triana, Wina, Zulkarnain, \& Rahma Kurnia. 2015. Pengaruh Model Pembelajaran Project Based Learning Terhadap Hasil Belajar Geografi Siswa Kelas XI IPS SMA AL-Azhar 3 Bandar Lampung Tahun Pelajaran 2014/2015. Jurnal Pendidikan. (Online), (http://jurnal.fkip.unila.ac.id, diakses 30 November 2019).

Trianto.2015. Model Pembelajaran Terpadu. Jakarta: Bumi Aksara.

Uno, Hamzah B. 2016. Teori Motivasi danPengukurannya. Jakarta: PT Bumi Aksara.

Wahyuni, Maya. 2017. Pengaruh Metode Mathemagics Terhadap Kemampuan Penalaran Matematis di Tinjau Dari Motivasi Belajar Siswa SMKN 1 Bandar Lampung Tahun Ajaran 2016/2017. Skripsi tidak diterbitkan. Lampung: Pendidikan Matematika IAIN Raden Intan.

Wena, Made. 2016. Strategi Pembelajaran Inovatif Kontemporer. Jakarta: Bumi Aksara.

Wisudawati, Asih Widi, \& Eka Sulistyowati. 2017. Metodologi Pembelajaran IPA. Jakarta: PT. Bumi Aksara.

Yamin, Moh. 2015. Teori dan Metode Pembelajaran. Malang: Madani. 